\title{
EUROPEAN SEAPORTS INFORMATION SYSTEMS. THE IMPACTS OF DIRECTIVE 2010/65/EU
}

\author{
Claudio Jose Pinto ${ }^{1}$, Pedro Fernandes Anunciacao ${ }^{2}$ \\ ${ }^{I}$ APS (Ports of Sines and Algarve Authority), Sines, Portugal, claudio.pinto@apsinesalgarve.pt \\ ${ }^{2}$ CICE-ESCE/IPS (Research Centre in Business Sciences) - Polytechnic Institute of Setúbal, Setúbal, Portugal, \\ pedro.anunciacao@esce.ips.pt
}

\begin{abstract}
Research purpose. The European Union recognizes the importance of information systems for improving the performance of trans-European transport network ports by promoting a set of initiatives focused on their use. The Directive 2010/65/EU obliges the provision of electronic services for the reception and treatment of declaratory acts necessary for the entry and exit of ships into the European Community and opens the way for future harmonization in the European Union of such services. The research purpose is to analyze and assess the degree of adequacy of European seaport information systems relative to the requirements of the European Directive to the availability of electronic services. Are they complying with the directive?

Design / Methodology / Approach. The objective of the study was to characterize the current situation of the main European seaports regarding the impacts of the European Directive. In this sense, it was decided to construct a survey to facilitate the identification and characterization of the options and actions taken by each country regarding the implementation of the Directive 2010/65/UE. This study was attended by the main EU Members and Norway.

Findings. From the analysis of the results of the European survey on the implementation of the Directive, we can conclude that the implementation of the Directive is carried out by entities of the State sphere. Member States show a low priority to the exchange of information between the Member States and the majority has not taken any action in this direction. With respect to the Single Window development model, the mixed model is the one adopted in most Member States.

Originality / Value / Practical implications. The central objective of Directive 2010/65/EU is to simplify and harmonize the administrative procedures required for maritime transport through electronic means. This Directive is seen as an opportunity to facilitate trade and administrative barriers through harmonization and standardization of the European Seaports Organization. The analysis of directive adoption represents an opportunity to increase scientific knowledge in this economic sector.
\end{abstract}

Keywords: Directive 2010/65/UE; Information; Interoperability; Seaports; Maritime transport; Single Window; Port Community System

JEL codes: M21; L91

\section{Introduction}

The main role of a port is to provide services for the movement of ships and goods (UNCTAD, 2004). Seaports are also places of cargo transfer from one means of transport to another and the transshipment has an important rule in the interaction with its hinterland (geographical area that uses the port for the flow of import and export of goods) (Notteboom, 2008) (Carbone \& Martino, 2003). Actually, seaports are important players in global logistics chains, and they should be considered as a cluster of organizations in which different transport and logistics operators are involved in the adding value to the final customer (Carbone \& Martino, 2003).

According to the OECD/ITF (2008), the three main factors of change in the organization of maritime transport are the containerization of cargoes, the emergence of global logistics chains, and the growing importance of container transshipment terminals. Containerization of cargo has led to a significant

(C) 2020 Authors. This is an open-access article licensed under the Creative Commons Attribution-NonCommercial-NoDerivs License (http://creativecommons.org/licenses/by-nc-nd/3.0/) 
degree of standardization of a seaport service (OECD/ITF, 2008), which has led to increased competition between seaports within the same area of influence. This trend has been enhanced by using increasingly larger ships with a large capacity container, reducing, on one hand, the number of ship scales and, on another, the range of ports with the capacity to receive them. The emergence of logistics chains on a global scale has led to a greater concentration of business (GS1, 2007). The third factor inducing change, referred by OECD/ITF (2008), is related to the growing importance of transshipment seaports. According to this organization, more than 20 of the world's 100 largest seaports are transshipment ports. According to the OECD/ITF (2015) this dynamic of transshipment traffic conditions the distribution pattern of maritime traffic in Europe. A hub-and-spoke network (load concentration at main terminals (hub) and redistribution on a smaller scale for target ports (spoke)) corresponds to a lower concentration of cargo in the destination ports and a more dispersed land transport.

Seaports are the main gateway to Europe's internal and external trade, playing a key role in Europe's economic growth and competitiveness (European Commission, 2009). According to the European Commission (2013a), 74\% of goods imported and exported, as well as 37\% of trade in the Union are carried out by seaports. This reality shows the European Union (EU) is a strong dependence on seaports not only from a commercial point of view but also as a guarantee of the cohesion of the European area. By ensuring regional and local maritime traffic services, linking peripheral and island areas, ports ensure the territorial continuity of the EU.

The preponderant role of seaports in the EU implies that these infrastructures are well developed and efficient. However, this is not a reality or, at least, is not the common denominator in the network of seaports in the EU. The European Commission (2013b) identifies disparities in port management in the EU compared to seaports ranked among the best worldwide in terms of efficiency. Most present serious structural problems, damaging and removing competitiveness to the regions that they serve and a whole EU. The disparities help to understand the reason why $20 \%$ of goods arriving by sea to Europe pass through only three seaports.

European Commission considers that there is a need to promote the high-performance seaports activities through strategic actions to connecting seaports to the trans-European network, modernizing port services, attracting investment, promoting social dialogue, improving the environmental profile, and encouraging innovation. And, through the Directive 2010/65/EU, the EU aims to increase the opportunity to facilitate trade and administrative barriers through harmonization and standardization of the European Seaports Organization.

The main objective of this research work is to evaluate the current situation of the European Seaports Organization and analyze the adequacy of their Information Systems to the requirement of the Directive.

\section{European transport policy}

The development of transport infrastructure in the EU has always been supported by the trans-European transport network policy (TENTEC). As mentioned by the European Commission (2011), this policy has been further developed since 1992 with the publication of the White Paper on Transport, the inclusion of the specific legal basis for the trans-European transport network in the Maastricht Treaty, and also with the approval, in 1994, at the Essen European Council, of a list of 14 priority projects.

Currently, the defined goals are still valid: contribute to the provision of efficient and effective transport systems to enable a high level of mobility for individuals and businesses, protect the environment, innovate and establish contacts at the international level. Factors such as EU enlargement, changes in the transport sector, innovation and new technologies, environmental commitments, energy consumption, or the permanent threat of terrorism have influenced successive revisions of European transport policy. Thus, in 1996 the European Parliament and the Council adopted the first guidelines for TENTEC policy and infrastructure planning. A significant revision of the guidelines was undertaken in 2004, considering EU enlargement and expected changes in traffic flows.

As part of the recommendations of the 2011 White Paper entitled "Roadmap to the single European transport area - Towards a competitive and resource-efficient transport system", the European 
Commission published, in December 2013, the latest revision of the guidelines for the development of TENTEC. As mentioned by the European Commission (2014a), this last revision defined for the first time the main network of transport infrastructure, which comprises all modes of transport, having defined the year 2030 as a deadline for its implementation. It is also mentioned by the European Commission (2014a) that the most difficult issues in the creation of the trans-European transport network are cross-border infrastructures, technical interoperability, and the integration of different modes of transport. To overcome these issues, the new guidelines introduce the concept of "core network corridors", whose implementation, within the above-mentioned deadline, has as its central concern the modal integration, interoperability, and coordinated development of infrastructures.

As mentioned by the Commission (2014b), this requires an ambitious policy needs and ambitious budget to accelerate its implementation. In this sense, the TENTEC has been allocated a budget of 26,250 million euros for the period 2014-2020, the financing of which is regulated by Connecting Europe Facility (CEF). Although this budget has tripled over the period 2007-2013, its value is insufficient compared to the identified needs of around EUR 250 billion for core networks. The CEF intends precisely to use the available financial resources in the priority axes defined in its regulation: projects for the construction or modernization of cross-border sections, elimination of «bottlenecks» on the main European traffic routes and implementation missing connections on the network.

\section{The centrality of Information Systems in port management and competitiveness}

In the port sector and maritime transport, Information Systems (IS) and Information and Communication Technologies (ICT) are essential tools in the management and efficiency (Mobility and Transport Authority, 2016) (Lee-Partrige, 2000). In this area, two concepts have gained importance, the Port Community Systems (PCS) and Single Window (SW). The latter, through EU policies, is now strongly encouraged to be extended to the entire European area and begins to be applied throughout the entire logistics chain.

The World Bank notes that $82 \%$ of the world's economies provide some form of electronically submitting to customs documents relating to the import, export, or manifests of goods (Doing Business, 2011). In the same publication, World Bank says that economies are taking additional steps in the implementation of Single Window systems involving all stakeholders of trade and freight. Single Window solutions are also being adopted at the regional level. The best example of regional initiatives is the ongoing project in the Asian sub-continent, involving both public and private stakeholders. The Association of Southeast Asian Nations (ASEAN) has an ongoing project ("ASEAN Single Window") which will connect several countries in the region with the aim of sharing the customs information required to retrieve their orders and licenses (ASEAN, 2013).

The EU strategy focuses on encouraging less efficient seaports to apply best practices and management methods (European Commission, 2013a), to mitigate the structural performance gaps between the various European seaports and to materialize the challenge of a fully integrated transport network. To this end, strategic actions include connecting ports to the trans-European network, modernizing port services, attracting investment, promoting social dialogue, improving the environmental profile of ports and encouraging innovation.

In addition to the structural asymmetries between seaports, in different moments and contexts, it is mentioned that the administrative burden imposed on maritime transport has the consequence of less attractive seaports, damaging its overall performance. Cost reduction and simplification of procedures are, therefore, a key factor for the promotion of maritime transport in the EU, and information systems can be important tools to achieve these objectives. The initiatives proposed by the European Commission (2013b), for which information systems can make an important contribution, fall within the strategic objective of modernizing seaport services regarding administrative simplification and their integration into logistics chains.

To this end, the European Commission (2013a) has decided to continue to develop its actions in: 
- the Blue Waist Initiative, which aims to reduce the administrative burden on EU prices transported by sea between EU ports to a level comparable to other types of transport, by further simplifying customs procedures;

- strengthening harmonization and coordination of the implementation of Directive 2010/65/EU, by establishing guidelines on national single points of contact;

- the e-maritime initiative, which aims to promote the use of electronic data in the conduct of business and reduce the administrative burden; and

- the e-freight initiative, which aims to facilitate the exchange of information along multimodal logistics chains and which will contribute to improving the efficiency of seaports, which are important multimodal platforms.

Whereas IS must be built with a clear understanding of the organization, including its surrounding environment (Laudon \& Laudon, 2010), in the case of Single Window or Port Community Systems solutions, this framework contains enormous challenges related not only to the technological aspects but also from an organizational, inter-organizational, management, political and legal point of view. In this context, Anunciação \& Zorrinho (2006) defend the concepts of Organizational Urbanism and Architecture as a way of managing this complexity. According to these authors, the implementation and governance of IS solutions must be carried out in a sustained way, with the efficient and effective management of available resources, ensuring the alignment between the development of the IS and the business strategy (Architecture) considering the national and international context to guarantee longterm success (Urbanism). These authors also underline that, although the architecture is the structural element of Urbanism, it is the responsibility of Urbanism to give context to architecture so that the architecture can respond to the specific requests of each system and organization. The only architecture allows alignment between business and IT (Hermans, 2015) (Rosa \& Oliveira, 2015) (Rodrigues, 2014) (Josey, 2011) (Lankhorst, 2005). Its value depends on the ability to integrate different perspectives and views (Zachman, 2016) (Zachman, 2008) (Sessions, 2007) (Pereira \& Sousa, 2004).

\section{Port Information Systems - Port Community Systems and Single Windows}

According to Long (2009), PCS has played an important role in mitigating the natural ports «bottlenecks», facilitating the movement of goods. Investment in this type of capacity easily competes with traditional investments (such as equipment, port docks, etc.), which are more easily perceived by the port community (Bezic et al., 2011). However, there is a growing interest in the investment of the seaports in these tools, to achieve greater efficiency and competitive advantage (Competition Authority, 2015). Dating to the decade of 80 of last century the appearance of the first applications in the European ports. The main benefits of PCS arising from its use are (Long, 2009): data entry manual work reduction; redundancy elimination in data entry and storage; and time reduction to obtaining the necessary orders for the movement of goods.

PCS is different in all seaports. The scope of services provided depends on the type of the seaport, the nature of the operations it carries out, its port community (Smit, 2014), the diversity of entities and needs that constitute a port community served by a PCS, which makes it a complex system (Tijan et al., 2009).

A Port Community System can be defined as:

- a holistic system, geographically delimited, that serving the interests of heterogeneous collective entities in a port community (Srour, van Oosterhout, van Baalen, \& Zuidwijk, 2007);

- an electronic platform linking multiple systems, operated by a variety of organizations, which constitute a port community (Rodon \& Ramis-Pujol, 2006);

- a neutral and open platform enabling public and private stakeholders to exchange secure and intelligent information in order to improve the competitive position of the airport and maritime port communities (IPCSA, 2011); 
- an instrument to increase port efficiency (Carlan, Sys, \& Vanelslander, 2015);

- a capability that allows all parties involved in trade and transportation to present, in a standard way and at a single point of contact, the information necessary to comply with the regulatory requirements inherent in the import, export, and transit (UN/CEFACT, 2005);

- the collecting, disseminating and exchanging information related to the movement of ships, with rules and data structures defined in a common way and management of access to information (European Commission, 2015).

The World Customs Organization (WCO), based on the definition presented in Recommendation No. 33, introduces the term Single Window Environment and adds the intelligent attribute to that definition (WCO, 2008). As clarified by the WCO the term Single Window Environment is used instead of the term Single Window, as it best translates the practical expression of its implementation. That is, the various existing implementations of this concept translate into the union or federation of several interdependent systems, interconnected by mutually agreed interfaces and collectively adopted business processes. The intelligent term is introduced because the Single Window Environment is not just a hub, switch, or gateway for a set of services, nor a mere web portal (UNECE, 2011). On the contrary, intelligent presupposes a set of value-added services for government entities and economic operators (WCO, 2011).

\section{The European Parliament and the Council Directive 2010/65/EU}

The central objective of Directive 2010/65/EU is to simplify and harmonize the administrative procedures required for maritime transport through the electronic means for their transmission (in the reception and distribution). This Directive is seen as an opportunity to facilitate trade and administrative barriers through harmonization and standardization as European Seaports Organization (ESPO, 2014) (ESPO, 2010) corroborates the Commission's objectives. Also, the International Port Community Systems Association (EPCSA, 2013a) (EPCSA, 2013b), underlines its line with the European policy on maritime and port sector, particularly with the recognition of the need for more simplification in helping ports to modernize the services offered through the use of electronic exchange of information.

This statement has an intrinsic complexity which implies the need to evaluate the following aspects: analyze the impacts and requirements in the organization (to "simplify" and "rationalize"), perform an analysis of the gap between formalities, identified in the Directive and those currently required (to harmonize and standardize), and to define the technological solutions that will achieve the objectives of the Directive (enabling "electronic transmission").

The Directive sets out four key requirements for its implementation: providing a single platform for data transmission by ships through the adoption of the SW concept, simplified and harmonized electronic transmission of reporting formalities in each EU Member States and between the EU Member States, declare the individual data only once, and information security.

\section{Research methodology}

The objective of the study was to characterize the current situation of the main European seaports and assess the degree of adequacy of information systems relative to the requirements of the Directive 2010/65/UE. The research question was: Are they complying with the requirements of the European Directive?

In this sense, it was decided to construct a survey to facilitate the identification and characterization the options and actions taken by each country regarding the implementation of the Directive 2010/65/UE.

This study was attended by the main EU Members and Norway. The survey was carried out not only for the entities responsible for implementing the Directive in each EU Member but also for the clients of the seaports, using, for this purpose, associations of shipping agents or equivalent entities. 
The preparation of the survey was based on the standards, guides and recommendations of the International Organization for Standardization (ISSO), International Maritime Organization (IMO) and European Maritime Safety Agency (EMSA), with closed answers, and was divided into five parts, namely:

- Identification of the respondent - identification of the entity, characterization, functions, and organization;

- Organization and management - characterization of the trends and options regarding the responsibility for implementing the Directive, and the scope and the way it has been implemented in the various countries (the central aspects analyzed were: the responsibility for SW governance, the need for reorganization, the need for process reengineering, the description of SW implementation, the entities integrated with the SW, the government benefits, the benefits to the business, the responsibility for financing the system, the Service Level Agreements (SLAs) with the SW service provider, the existence of Service Desk service, the existence of change management procedures, the number of entities managed, the number of users managed, the current project development phase, the level of compliance with the harmonization of the Directive in the country, and the level of compliance with the harmonization of the Directive at European level);

- Information - identification of the scope of information processed and the references used to share it: the declarative acts identified in the Directive and considered within the scope of SW implementation, the additional services provided by SW beyond those of the Directive, the standards and guides adopted for the exchange of information, the types of executive orders made available to the industry, the relevant options in the context of the exchange of information between the Member States, the agreement with the re-use of information in the business context, the accordance with the need for authorization of the information owner for the exchange of information between the EU Member States, the sharing of current information with another EU Member State;

- Technology (Architecture, Integration, and Communications) - characterization of the technological solutions implemented, with respect to the model (s) adopted for the architecture of the solutions, the role of the PCS in this architecture, the use of cloud concepts, the type of interfaces used to exchange information between partners and the use of solutions for mobile platforms (namely, the model that characterizes your SW implementation, the point of contact for respondents, the number of different PCS used by respondents, the adoption of the cloud-ready concept in SW development, the purpose in the use of SafeSeaNet at a national level if SW is supported in the cloud, the types of models used, the use of cloud service types (IaaS, PaaS or SaaS), the characterization of SW in the respective country, the interfaces available to respondents and Authorities, the channel(s) used in stakeholder interconnection, the entities integrated between systems, the technologies used to exchange information between stakeholders, the redundancy of SW support infrastructure, and the planning mobile application development;

- Technology (Security) - identification of the approach of the various countries with regard to information security, measures and methodologies adopted (namely, the existence of an Information Security Management System (ISMS) for the scope of the Single Desk, the certification of ISMS according to ISO 27001, the existence of an information security plan, the conducting internal or external audit actions, the existence of security incident management procedure(s), the existence of disaster recovery plan, the technologies used to protect communication channels, and the use of the digital signature mechanism for declarative acts, or other services offered in SW. 


\section{Research results}

As regards the first part of the study, identification of respondents, all Member States with a maritime border were invited to participate. We obtained responses from 11 countries (Belgium, Denmark, Germany, Italy, Latvia, Norway, Portugal, Slovenia, Spain, Sweden, and the Netherlands). The countries participating in this study are representative of European maritime goods traffic. In this respect, with the exception of France and the United Kingdom, the main European players representing $70 \%$ of the maritime traffic of goods in the European space, to which the only three European ports of the world top 20, in relation to the handling of containerized cargo, and nine seaports of the European top 10, of the same cargo segment.

Regarding the remaining chapters under study, the results show the following:

- Organization and Management Chapter:

- 75\% of countries identify government structures and Public-Private Partnerships as responsible for SW governance. In $82 \%$ of cases, it is the responsibility of the State to finance the SW. Only Italy assumes the charge of some type of fee on the services offered in SW;

- $90 \%$ of respondents say they have set up structures to coordinate SW implementation. However, only $50 \%$ have implemented a formal change management process. It is also verified that $50 \%$ of the respondents affirm that a process re-engineering was not carried out;

- $90 \%$ offer a Service Desk. However, only $40 \%$ have established a service level agreement;

- $70 \%$ state that the implementation of SW considered not only the requirements related to the means of transport but also those related to the movement of the goods transported in them. Only one country states that it does not identify with the options presented to characterize the scope of SW. The results obtained also demonstrate that the scope of most implementations is focused on the management of the declarative acts provided in the Directive;

○ only the Port Authority and the Border Authority are involved in all the implementations;

○ in only 4 countries (Spain, Italy, Portugal, and Sweden) are all the authorities involved;

- most solutions generate less than 1,000 entities and between 500 and 5000 users;

- $20 \%$ of the answers obtained affirm that the project of implementation of SW solutions is finished;

○ there is a good degree of satisfaction with the benefits achieved (Figure 2). Regarding the private or business sphere (Figure 3 ) the results obtained is more modest;

- only Latvia claims to have achieved the harmonization objective in the Directive, both at the level of its country and in Europe;

- $70 \%$ claim, at the national level, partial compliance with harmonization. At European level, even considering a partial fulfillment of this objective, the answers are modest $(30 \%)$;

- the main success factors in the implementation of SW and Directive 2010/65/EU in the respective countries are the cooperation with another member state in the specification of an excel for bulky data, a single entity responsible for implementation, the good collaboration between stakeholders and member states, the re-use of existing capacity with regard to PCS, the well-defined project management structure, the formal tests, and the full-time project manager;

o the main obstacles in the implementation of the SW and Directive 2010/65/EU in the respective countries are the lack of integration and common specifications at the EU 
Member States level, the lack of agreement/collaboration at the European level, the failure of internal project coordination due to the internal organization of an MS (regional and/or federal differences), the absence of the reengineering process (implementation of solutions that only intend to "computerize the paper"), the ignorance about computer project management, the Part $\mathrm{C}$ of the Directive lead to a lack of harmonization, the lack of commitment and knowledge of shipowners on the development of projects, and the short implementation time.

- Information Chapter:

- not all declaratory acts identified in the Directive will be considered within the scope of SW implementation in all EU Member States (immediate or future). This is particularly evident for declaratory acts «Ship's store's declaration», «Crew's effects declaration», «Maritime declaration of health», and «Entry summary declaration». It is also clear that there is no motivation to add services other than those of the Directive;

- maneuver services are included in the solutions of four countries and that only 2 countries include billing services and utilities;

○ there is no harmonization between the Member States. Not considering UN/EDIFACT standards, the two other options that are most identified are "custom" specifications (AnNa - Advanced National Networks for Administrations, specifications presented by the consortium of 14 MS-or own). The same trends occur in the exchange of information with the reporting entities and other entities, in particular with the authorities;

0 the declarative acts related to information about the goods are those that do not appear in the preferences for the exchange of information between the Member States. It should be noted that $70 \%$ of the responses indicate that this information exchange should be kept at the governmental level and $75 \%$ of respondents indicate that the reporting agent should give explicit permission to share this information with another Member States. Finally, it is verified that only $25 \%$ exchange some information with another Member States.

- Technology Chapter (Architecture, Integration, and Communications):

0 there is no predominant architecture model. The purely decentralized model is the least used (18\% of cases), with mixed and centralized models being the most predominant;

- $70 \%$ of countries confirm the availability of a single point of contact for respondents. It should be noted that responding countries using more than three PCS belong to some of the main European ports (Germany, Belgium, and Spain);

O the cloud concept in the implementation of SW is still little used in the solutions implemented in the various countries. $67 \%$ of the answers indicate that SW was not developed under the concept of "cloud-ready";

- $67 \%$ of responses point to the hybrid model and no one considers using the public model alone. Still, on this topic, $67 \%$ of respondents say that they do not use any cloud service (IaaS, PaaS or SaaS);

o SafeSeaNet systems are used in most countries to exchange information between authorities;

- most of the solutions are built on a 3-tier architecture, there is no clear predominance between programming languages (.Net or Java). The predominant communication protocol is SOAP and that the use of technologies associated with process management and orchestration services have little expression;

○ the applications for mobile solutions are still the type of interface less available; 
- the type of interface mostly available corresponds to the web applications. Already for the exchange of information with the Authorities, the type of interface mostly available is the integration between systems;

○ the Internet is the channel used for the exchange of information. There are few cases where they additionally use dedicated lines for the purpose;

o it is clear the option to use web services (69\%), against the use of FTP, email or other technologies;

0 there is a greater development in the integration between systems with the authorities and less with the service providers and other actors in the transport chain. Regarding the authorities, this type of integration is more widespread with the Border and Seaport Authority;

- $67 \%$ of respondents have redundant SW support plans or infrastructures;

- The results show that mobile applications in the context of SW are a trend with little preponderance. Nevertheless, among the answers that claim to have developed this type of applications it turns out the Android system, has greater relevance.

- Technology Chapter (Security):

- only $44 \%$ have an Information Security Management System (ISMS) defined for the SW, and only $10 \%$ of those have their ISMS certified based on ISO 27001;

- all countries that do not have an ISMS implemented, do not have in their plan to do so either;

○ only $30 \%$ have plans implemented for training and awareness, audits and management of security incidents;

$\circ$ in the case of training and awareness and management of security incidents, this percentage increases of around $55 \%$ and $80 \%$, respectively, if we take into account the plans for the future;

○ $60 \%$ have a disaster recovery plan;

- $50 \%$ claim to use the digital signature mechanism;

○ the https protocol represents the most used technology options for security of the communication channels (60\%), followed by the VPN (20\%).

\section{Conclusions and recommendations}

From the analysis of the results of the European survey on the implementation of the Directive, presented in the previous points, we can conclude as the most relevant aspects evidenced by the Member States the following:

- the implementation of the Directive is carried out by entities of the State sphere, which is responsible for its financing;

- $\quad$ practically all member states have established structures to coordinate SW implementation. However, only half of the MS have adopted change management methodologies and process reengineering;

- most Member States closes the solution around the reception of declaratory acts of the Directive and in the respective Declarants and Authorities;

- Member States are more confident of the benefits achieved in the governmental sphere than in the sphere of business. It should be noted that the Member States believe more in achieving benefits in terms of efficiency and transparency and less in reducing costs; 
- generally, Member States do not include coverage of the entire scope of the Directive with regard to reporting formalities, and it is also clear that there is no motivation to add other services in their solutions (operations, billing, payment, among others);

- all solutions provide some sort of executive orders from the authorities. However, the solutions covering the various executive orders are a minority;

- there is no harmonization regarding the references used for the specification of electronic messages for the sharing of information between actors, there being a fair distribution between the adoption of industry standards and own specifications;

- Member States show a low priority to the exchange of information between them, and the majority has not taken any action in this direction. Regarding this issue, the Member States express reservations about the scope of the information exchanged and even that which they admit to exchanging with the other Member States mention that it should be confined to the governmental sphere;

- with respect to the SW development model, the mixed model is the one adopted in most Member States. However, there is no predominance of any of the models;

- there is a clear difference between the countries to which the main European ports belong and the remaining ones, as regard the solution adopted for the reception of reporting formalities. In the first, the various PCS in the ports were used, while in the seconds it was decided to provide a Single Point of Contact;

- the integration between systems, for information sharing, has greater expression among Authorities. Respondents use mostly web applications for data entry;

- the Member States evidenced no plans to adopt new trends in ICT (cloud or mobile applications) in the solutions developed for the SW;

- in spite of some actions implemented in the scope of Information Security, the majority of MS do not show a systematic treatment of this issue.

Lastly, it should be pointed out that the MS is adamant that the objective of the Directive on the harmonization of reporting formalities has not been achieved, internally in each MS and especially at the EU level.

\section{References}

Anunciação, P. F. \& Zorrinho, C. (2006). Organizational Urbanism - How Managing Technological Shock in Companies, Lisbon, Sílabo Publishing (In Portuguese)

ASEAN. (2013). About ASEAN Single Window. Retrieved June 21, 2016, from http://asw.asean.org

Bezic, H., Tijan, E., \& Aksentijevic, S. (2011). Port Community Systems: economic feasibility evaluation. Osijek: University of Osijek

Carbone, V., \& Martino, M. (2003). The Changing role of ports in supply-chain management: an empirical analysis. London: Taylor \& Francis

Carlan, V., Sys, C., \& Vanelslander, T. (2015). Port Community System cost and benefits: from competition to collaboration within the supply chain

Competition Authority. (2015). Study on competition in the port sector (In Portuguese)

Doing Business. (2011). Doing Business 2012: Trading Across Borders. The World Bank

EPCSA - European Port Community Systems Association - (2013a). EPCSA Policy Statement - May 2013: EU Port Policy Proposals

EPCSA - European Port Community Systems Association - (2013b). Message Standards in the EU

ESPO - European Sea Ports Organisation. (2010). European Port Governance. Brussel: ESPO 
ESPO - European Sea Ports Organisation. (2014). Position of the European Sea Ports Organisation on the implementation of reporting formalities Directive 2010/65/EU. Bruxelas: ESPO

European Commission. (2009). Communication from the Commission to the European Parliament, the Council, the European Economic and Social Committee and the Committee of the Regions, "Strategic goals and recommendations for the EU's maritime transport policy until 2018. COM(2009) (In Portuguese)

European Commission. (2011). Proposal for a Regulation of the European Parliament and of the Council on Union guidelines for the development of the trans-European transport network. COM (2011) 650 final (In Portuguese)

European Commission. (2013a). Blue Waist, a unique space for growth. COM(2013) 510 final (In Portuguese)

European Commission. (2013b). Ports an engine for growth. COM(2013) 295 final (In Portuguese)

European Commission. (2014a). Building the main transport network: the main network corridors and the Connecting Europe Facility. COM(2013) 940 final

European Commission. (2014b). Report from the Comission to the European Parliament and the Council: "on the functioning of Directive 2010/65/EU on reporting formalities for ships arriving in and/or departing from ports of the Member States. $\operatorname{COM}(2014) 320$ final

European Commission. (2015). National Single Window Guidelines. Directorate General for Mobility and Transport, Directorate D - Logistic, maritime \& land transport and passenger rights, Brussels

GS1. (2007). Logistics Interoperability Model, Version 1

Hermans, P. (2015). The Zachman Framework for architecture revisited. On conceiving the informational enterprise. Retrieved May 18, 2016, from www.zachman.com

IMO. (2011). Guidelines for setting up a Single Window System in maritime transport. FAL.5/Circ.36

IPCSA. (2011). White Paper: The role of Port Community Systems in the development of the Single Window. Brussels

ISO 28005-1. (2013). Security management systems for the supply chain - Electronic port clearance (EPC) - Part 1: Message structure

ISO/IEC/IEEE 42010. (2011). Systems and software engineering - Architecture description

Josey, A. (2011). TOGAF Version 9.1 Enterprise Edition: An Introduction. Retrieved June 10, 2016, from https://www2.opengroup.org/ogsys/catalog/W118

Lankhorst, M. (2005). Enterprise Architecture at work: Modelling, communication and analysis. New York: Springer

Laudon, K. C., \& Laudon, J. P. (2010). Management Information Suystems: Managing the digital firm. New Jersey: Pearson

Lee-Partrige, J., Teo, T., \& Lim, V. (2000). Information technology management: the case od the Port of Singapore Authority. Jornal of Strategic Information Systems, 9(1), 85-99.

Long, A. (2009). Port Community Systems. World Customs Jornal, 3, 63-67

Mobility and Transport Authority. (2016). Follow-up of the Port Market: Report for December 2015 (In Portuguese)

Notteboom, T. (2008). The relationship between seaports and the intermodal hinterland in light of global supply chain. Paris: OECD/ITF

OECD/ITF. (2008). Port Competion and hinterland connections. Paris: OECD/ITF

OECD/ITF. (2015). The impact of Mega-Ships. Paris: OECD/ITF

Pereira, C. M., \& Sousa, P. (2004). A method to define an enterprise architecture using the Zachman Framework. Nicosia, Cyprus: SAC '04

Rodon, J., \& Ramis-Pujol, J. (2006). Exploring the intricacies of integrating with a Port Community System. 19th Bled eConference. Bled

Rodrigue, J. (2010). Maritime Transportation: Drivers for the Shipping and Port Industries. Leipzig: OECD/ITF 
Rodrigues, L. (2014). Determining Factors of the Value of Enterprise Architectures, New Academic editions Publishing (In Portuguese)

Sessions, R. (2007). A comparison between the four main methodologies of corporate architecture. Retrieved June 10, 2016, from https://msdn.microsoft.com/pt-br/library/bb466232.aspx_(In Portuguese)

Smit, S. (2014). A Comparison of Port Community Systems: A framework to compare Port Community Systems and an application to the Port Community Systems of Hamburg, Rotterdam and Antwerp. Rotterdam: Master Thesis

Srour, F. J., van Oosterhout, M., van Baalen, P., \& Zuidwijk, R. (2007). Port Community System Implementation: Lessons Learned from an International Scan. Rotterdam

Tijan, E., Kos, S., \& Ogrizovic, D. (2009). Disaster Recovery and Business Continuity in Port Community Systems. Rijeka: University of Rijeka

Tsen, J. K. (2001). Ten years of Single Window implementation: Lessons learned for the future. Global Trade Facilitation Conference 2011

UN/CEFACT. (2005). Recommendation and Guidelines on establishing a Single Window: to enhance the efficient exchange of information between trade and government. United Nations, The United Nations Center for Trade Facilitation and Electronic Business. Geneva: United Nations Publications

UNCTAD. (2004). Assessment of seaport land interface: an analytical framework. UNCTAD. UNCTAD/SDTE/TLB/MISC/2004/3

UNECE. (2011). Single Window Implementation Framework. Geneva and New York

Van Oosterhout, M., Zielinski, M., \& Tan, Y. (2000). Inventory of flows \& processes in the port. Virtuele Haven [Virtual Port], deliverable T2.Dla

WCO. (2008). Single Window Information Store. Retrieved May 10, 2016, from http://www.wcoomd.org/en/topics/facilitation/activities-and-programmes/single-window/single-window.aspx

WCO. (2011). WCO Compendium: How to build a Single Window Environment, Volume 1 The executive guide. World Customs Organisation

Zachman, J. (2008). John Zachman's concise definition of the Zachman Framework. Retrieved May 18, 2016, from www.zachman.com

Zachman, J. A. (2016). The framework for enterprise architecture: background, description and utility. Retrieved June 22, 2016, from www.zachman.com 